\title{
Harold W. Attridge
}

\section{Essays on John and Hebrews}

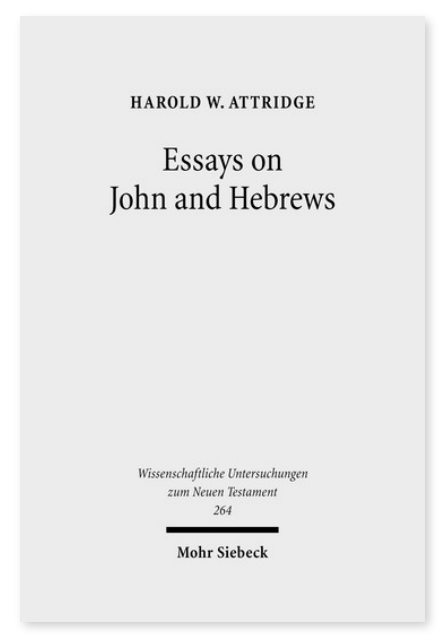

2010. XI, 443 Seiten. WUNT I 264

ISBN 978-3-16-151553-8

DOI 10.1628/978-3-16-151553-8

eBook PDF $159,00 €$

ISBN 978-3-16-150319-1

Leinen $159,00 €$
[Aufsätze zum Johannesevangelium und dem Brief an die Hebräer.]

Veröffentlicht auf Englisch.

Harold W. Attridge untersucht die literarischen und kulturellen Traditionen, die im Johannesevangelium und im Hebräerbrief wirksam sind, sowie die Rhetorik der beiden Schriften, die darauf zielt, den Glauben an Christus zu vertiefen, indem sie seinem Tod und seiner Erhöhung eine neue Bedeutung zuschreiben. Attridges Studien zu Johannes konzentrieren sich auf die literarische Kunstfertigkeit der letzten Fassung des Evangeliums, auf die spielerische Annäherung an literarische Genera, seine einnehmende Rhetorik und seine Freude Visualität. Er plaziert die literarische Analyse beider Werke innerhalb des religionsund kulturgeschichtlichen Kontexts des ersten Jahrhunderts unter Berücksichtigung der jüdischen und griechisch-römischen Welt. Einige Aufsätze, die das Phänomen im Zusammenhang mit dem Gnostizismus thematisieren, erweitern den religionsgeschichtlichen Horizont in das Leben der Frühkirche hinein und tragen zum Verständnis der Rezeption dieser zwei frühchristlichen Meisterwerke bei.

Harold W. Attridge Born 1946; 1967 A.B. Boston College; 1969 B.A. Cambridge University; 1975 PhD Harvard University; currently Sterling Professor of Divinity, Yale Divinity School.
Jetzt bestellen:

https://mohrsiebeck.com/buch/essays-on-john-and-hebrews-9783161515538?no_cache=1

order@mohrsiebeck.com

Telefon: +49 (0)7071-923-17

Telefax: +49 (0)7071-51104 